\title{
Deep-water seed populations for red tide blooms in the Gulf of Mexico
}

\author{
Linda G. Waters ${ }^{1,2, *}$, Thomas G. Wolcott ${ }^{1}$, Dan Kamykowski ${ }^{1}$, Geoff Sinclair ${ }^{1,3}$ \\ ${ }^{1}$ North Carolina State University, Raleigh, NC 27695, USA \\ ${ }^{2}$ Present address: Instituto Oceanografico, University of São Paulo, SP 05508-120, Brazil \\ ${ }^{3}$ Present address: US Environmental Protection Agency, Crystal City, VA 22202, USA
}

\begin{abstract}
Populations of the toxic dinoflagellate Karenia brevis that remain near the benthos in deep shelf water in the Gulf of Mexico could be the source for toxic bloom occurrences near shore. A biophysical dynamic simulation model and migrating drifters were used to assess whether such 'seed populations' could persist in nature. The vertical migration responses of plankton to an exclusively benthic nutrient source and light limitation would result in near-benthic behavioral trapping of a slowly growing population in conditions found on the West Florida Shelf (WFS). The model indicated that for a $50 \mathrm{~m}$ deep bottom, a 2-m-thick layer of $\geq 2 \mu \mathrm{mol} \mathrm{NO}_{3}{ }^{-} / \mathrm{NO}_{2}{ }^{-}$fluxing from the benthos was the minimum needed to permit growth for darkadapted $K$. brevis in an oligotrophic water column. Growth rates depended more on the duration of exposure to nutrients than on concentration; a 1-m-thick nutrient layer sustained minimum growth levels independently of the nutrient distribution at depths $\leq 40 \mathrm{~m}$. Field experiments using Autonomous Behaving Lagrangian Explorer drifters (ABLEs) that exhibited biomimetic vertical migration responses to the external environment demonstrated a benthically-oriented movement pattern in response to natural light and cues correlated with elevated near-benthic nutrients. Average measurements of nutrients and light from the bottom $2 \mathrm{~m}$ of the water column in a potential bloomforming region of the WFS were higher than the model-generated requirements for growth, suggesting that coastal nutrient distributions could support a benthic population offshore. Under upwelling conditions, such populations could be advected inshore to frontal convergence zones and form toxic 'red tide' blooms.
\end{abstract}

KEY WORDS: Harmful algal blooms - Benthic orientation - Karenia brevis - Nutrient limitation . Biomimetic $\cdot$ Lagrangian drifter

Resale or republication not permitted without written consent of the publisher

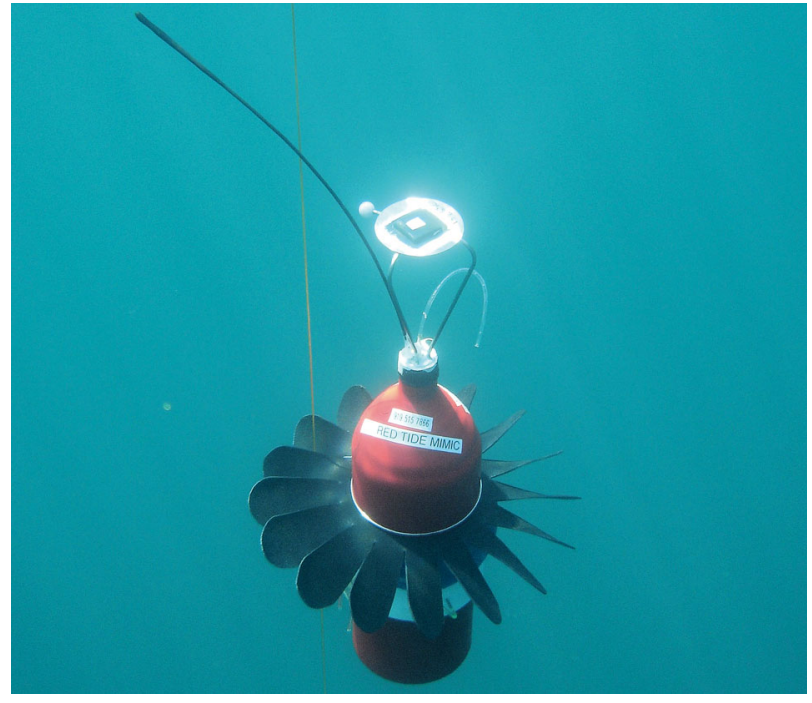

A Lagrangian drifter changing depth in 'response' to light and simulated nutrients using cellular uptake rates of Karenia brevis.

Photo: Linda Waters

\section{INTRODUCTION}

Karenia brevis, a toxic dinoflagellate endemic to the Gulf of Mexico (GOM), has been detected near the surface at background concentrations (10 to 100 cells l$^{-1}$ ) (Finucane 1964) year-round (Geesey \& Tester 1993). These toxic phytoplankton in the GOM can form dense aggregations (or blooms) following upwelling or downwelling conditions and during the breakdown of vertical stratification (Walsh et al. 2003). Adverse economic and ecological consequences have generated considerable interest in the mechanisms of bloom formation, knowledge of which would aid predictive modeling of impact zones. The neurotoxins 
(Shimizu et al. 1995) associated with the periodic blooms of Karenia brevis frequently affect not only tourism but also ocean and human health along the heavily populated shorelines near the West Florida Shelf (WFS) (Steidinger \& Ingle 1972, Steidinger 1983, Kirkpatrick et al. 2004).

Karenia brevis blooms on the WFS often form after upwelling events, which transport subsurface water shorewards (Stumpf et al. 2008), suggesting that a source population for the bloom 'seed' cells may be surviving offshore near the benthos. Even though the majority of the water column along the shelf of the GOM is typically oligotrophic in the upper water column $(<0.1 \mu \mathrm{mol} N)$, and growth rates of marine plankton are typically nitrogen limited (Hecky \& Kilham 1988), blooms of $>10^{4}$ cells $\mathrm{l}^{-1}$ appear to form at the surface 18 to $24 \mathrm{~km}$ offshore (Steidinger 1975, Tester \& Steidinger 1997). K. brevis is efficient at nitrogen accumulation in low concentration conditions, indicated by its low half-saturation rate of nitrogen uptake, $K_{\mathrm{s}}=0.06$ to $1.07 \mu \mathrm{mol} \mathrm{N}$ (Steidinger et al. 1998, Bronk et al. 2004), and can further enhance accumulation efficiency by increasing uptake rates after prior low-nutrient exposure (Sinclair et al. 2006a). A variety of nitrogen forms present in porewater along the WFS (Sinclair \& Kamykowski 2008) and subsequently fluxing from the sediment could sustain a diffuse $K$. brevis population (Sinclair et al. 2006b). K. brevis cells near the benthos could be transported shoreward by upwelling, become concentrated in frontal regions (Janowitz \& Kamykowski 2006, Walsh et al. 2006), and subsequently form surface blooms. Red tide blooms commonly form along the WFS in the fall, when upwelling favorable conditions are likely (Weisberg \& He 2003).

$K$. brevis is motile, performing diel vertical migrations (DVM) (van Dolah \& Leighfield 1999), and adapted for both low-light (Shanley \& Vargo 1993, Magaña \& Villareal 2006) and low-nutrient conditions (Sinclair et al. 2006a,b, 2009), such as would be expected in offshore near-bottom water along the oligotrophic shelf of the GOM. Bloom formation has previously been assessed using surface sampling, but if these photosynthetic dinoflagellates migrate down to utilize a benthic nutrient source and bottom depth is $>15 \mathrm{~m}$, they are unlikely to reach the surface during their upward migration for light. DVM (described by Heil 1986, Kamykowski et al. 1998a, van Dolah \& Leighfield 1999) at speeds averaging $1 \mathrm{~m} \mathrm{~h}^{-1}$ (McKay 2004) would allow K. brevis to utilize light and nutrients separated by up to $12 \mathrm{~m}$. Near-bottom aggregations of other dinoflagellates (Kamykowski 1974, Cullen \& Horrigan 1981) as well as individual
K. brevis cells have been observed offshore in deep water during the ECOHAB cruise series. We hypothesized that regions of the WFS where light levels are above the minimum threshold for photosynthesis by K. brevis (Magaña \& Villareal 2006) within diel vertical migration distance of the benthos can support populations of potential 'bloom-seeding' $K$. brevis cells (Fig. 1).

Dinoflagellates have the ability to modulate their migration depth according to nutrient and light availability (Cullen \& Horrigan 1981, Cullen 1982, Kamykowski et al. 1998a). These 2 factors will determine whether subsurface populations can maintain a benthic orientation (migrating between the benthos and a region with sufficient light for photosynthesis) and persist over multiple generations. The speed of vertical migration for $K$. brevis is thought to be modulated by the relative intracellular levels of carbon (photosynthate) and nutrients (nitrate and phosphate) (Kamykowski \& Yamazaki 1997, Kamykowski et al. 1998a, McKay 2004). Since the vertical distribution of nutrients determines the maximum depth to which the dinoflagellates will migrate and therefore their exposure to light, near-benthic GOM water was analyzed for nutrient content, as well as for vertical gradients that might serve as orientation cues near the benthos. Behavior of biomimetic robot drifters (Autonomous Behaving Lagrangian Explorers, 'ABLEs') then determined whether biologically based 'swim-

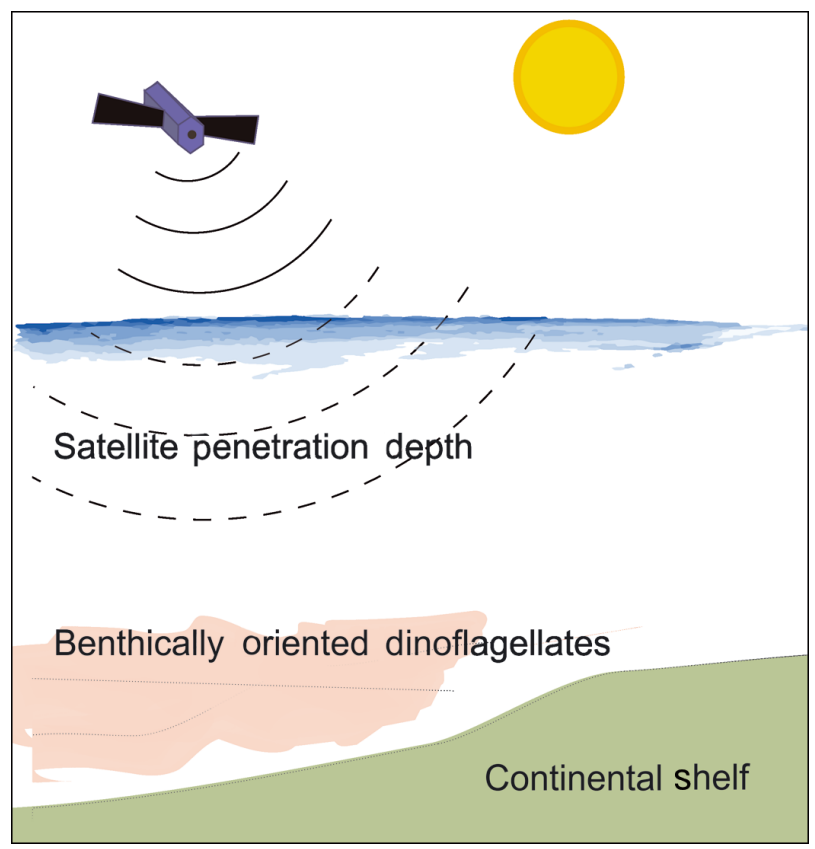

Fig. 1. Visualization of the possible position of a nearbenthic 'seed' population in the months prior to Karenia brevis toxic bloom formation 
Fig. 2. Two cross-shelf transects made during the BenDiM2 (October 2008) and BenDiM3 (July 2009) cruises. Circles: CTD cast locations (both cruises); stars: benthic lander sampling locations (2009 cruise). Inset map: location of the sampling site on the Florida panhandle. Isobaths are calculated with 3 arcsecond resolution from the NOAA NGDC U.S. Coastal Relief Model, indicated by grey lines in $10 \mathrm{~m}$ increments. The coastline, black with grey internal shading, was obtained from NOAA NGDC extracted coastline data (GSHHG). NOAA NGDC data was accessed from http:// www.ngdc.noaa.gov/mgg/shorelines/ shorelines and http://www.ngdc.noaa.gov/ $\mathrm{mgg} / \mathrm{coastal} / \mathrm{crm} . \mathrm{html}$ on 4/1/2015. A variation in the precise location chosen for the station occurred between years at the $40 \mathrm{~m}$ isobath, accounting for the appearance of an 'extra' station

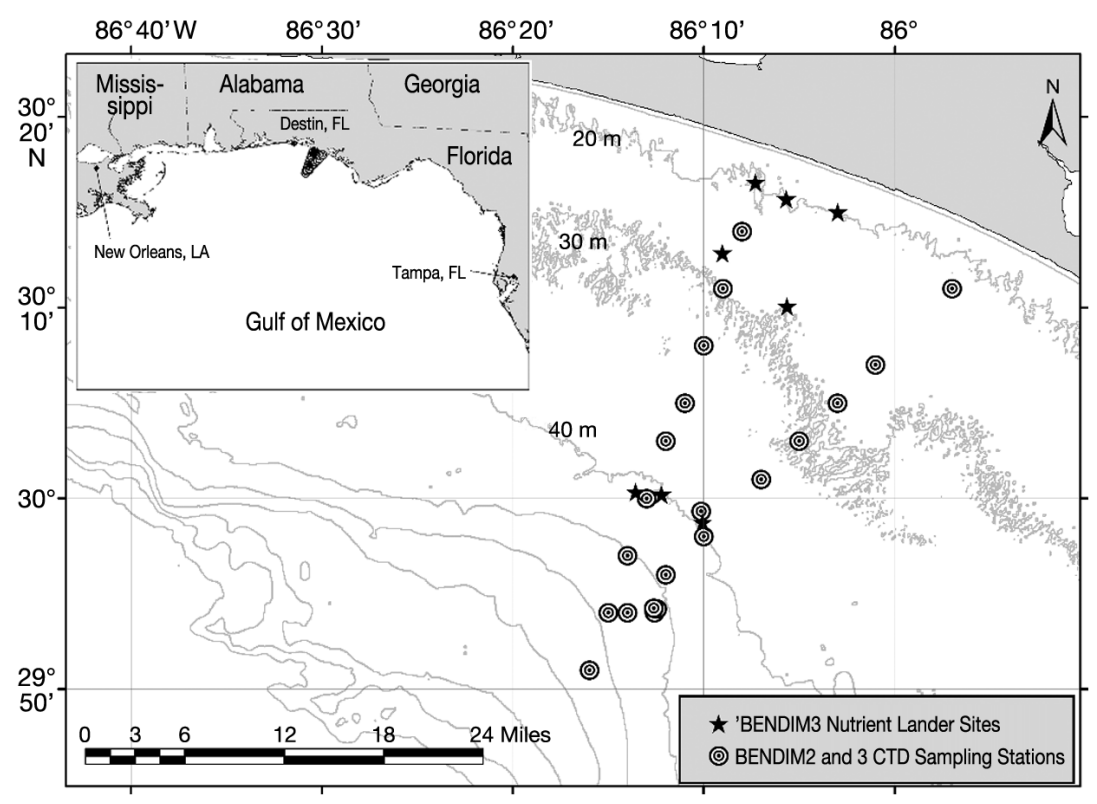

ming rules' would result in bottom-oriented migration behavior in the presence of vertical distributions of $\mathrm{N}$ that would result from benthic efflux or nearbottom, up-slope upwelling, even when the surface is within potential swimming distance of the benthos. To assess whether such near-bottom populations could persist throughout the year, a simple biophysical model was developed in which the cells migrate between the 2 essential resources - light and nutrients. The swimming speed was dependent on the cells' relative need for photosynthate or nutrients (Yamazaki \& Kamykowski 2000, Liu et al. 2001a). If nutrient-limited $K$. brevis can maintain continuous bottom-oriented swimming behavior and reach cell division using natural in situ light, a near-benthic 'seed' population could persist over time.

\section{MATERIALS AND METHODS}

\section{Water column sampling}

Near-bottom profiler

Whether or not near-benthos water over the WFS in the GOM contains nutrients sufficient to sustain a benthic $K$. brevis population was examined offshore from Destin, FL, USA (centered around $30.141^{\circ} \mathrm{N}$, $86.130^{\circ} \mathrm{W}$ ) (Fig. 2), an area where red tide blooms are known to occur, using the R/V 'Pelican' in October 2008 and July 2009 during the BenDiM2 and BenDiM3 cruise series, respecitvely. Blooms were not present at that site during those 2 cruises; we wished to study the environmental conditions for dinoflagellates during periods when blooms were not occurring. The limiting nutrient $\mathrm{N}$ for $K$. brevis (Odum et al. 1955, Bein 1957), using $\mathrm{NO}_{3}{ }^{-}$and $\mathrm{NO}_{2}{ }^{-}$ levels, was measured in near-benthic water at 3 sampling locations along each of the 20,30, and $40 \mathrm{~m}$ isobaths. In 2009, to measure undisturbed nearbottom nutrient distributions, a prototype water sampler (Fig. 3) collected 14 simultaneous $\sim 30 \mathrm{~cm}^{3}$ samples from $10 \mathrm{~cm}$ to $2 \mathrm{~m}$ above the bottom, at 10 to $20 \mathrm{~cm}$ increments. The sampling chambers were mounted on a tripod lander that was triggered remotely a few minutes after landing to prevent contamination with water from other depths. Water was filtered immediately $(\mathrm{GF} / \mathrm{F}, 0.7 \mu \mathrm{m})$, then frozen $\left(-20^{\circ} \mathrm{C}\right)$ until $\mathrm{NO}_{3}{ }^{-} / \mathrm{NO}_{2}{ }^{-}$analysis was performed (courtesy of the J. Burkholder Lab, North Carolina State University) using a Lachat Instruments Quickchem 8000 Autoanalyzer. Calibration of the Lachat was conducted with low-nutrient seawater, collected from a depth of $50 \mathrm{~m}$ in the Gulf Stream off the North Carolina coast by the R/V 'Cape Hatteras'.

\section{CTD sampling}

To determine whether near benthic nutrient availability is inversely related to changes in available light near the sea floor, due to reduced competition for resources in low light, we measured the vertical attenuation of photosynthetically active radiation (PAR), along with the distribution of phytoplankton, in relation to temperature, salinity, and a coarse 


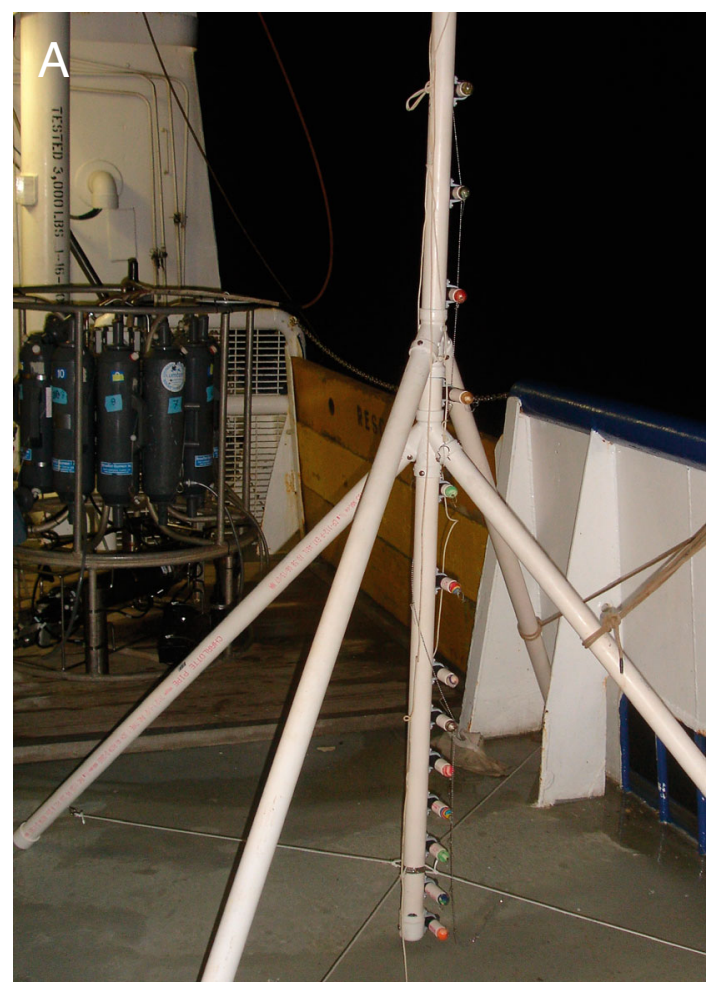

profile of $\mathrm{NO}_{3}{ }^{-} / \mathrm{NO}_{2}{ }^{-}$concentrations, from the R/V 'Pelican' along 2 transects during cruises in October 2008 and July 2009. The Brunt-Väisälä frequency was also calculated from that data within Ocean Data View (ODV) (Schlitzer 2012) to indicate areas of vertical stratification within the water column; this being the frequency that a parcel of water would oscillate around its original depth due to buoyancy if perturbed vertically, with large values indicating stability. PAR was measured using a Biospherical Instruments 2-QSP-200L and Surface QSR sensor, and chl $a$ was measured by a Chelsea Instruments Aquatraka III mounted to the top of a $\sim 1.5 \mathrm{~m}$ tall Sea-Bird CTD rosette that measured salinity, temperature, and depth using the Seabird SBE-9+. Nine stations were occupied along each of 2 transects forming a V-shape with respect to the shoreline and with a small variation in precise location of 2 of the stations between cruises, close to the locations of the nutrient lander sampling stations. $\mathrm{NO}_{3}{ }^{-} / \mathrm{NO}_{2}{ }^{-}$concentrations were measured at multiple depths with a Satlantic ISUS sensor using water collected via Niskin bottles during the profiling cast. During October 2008, however, the simultaneous collection of near-bottom nutrient samples using a previous design of the nutrient lander was unsuccessful due to bottle contamination. These $\mathrm{NO}_{3}{ }^{-} / \mathrm{NO}_{2}{ }^{-}$concentrations were compared to

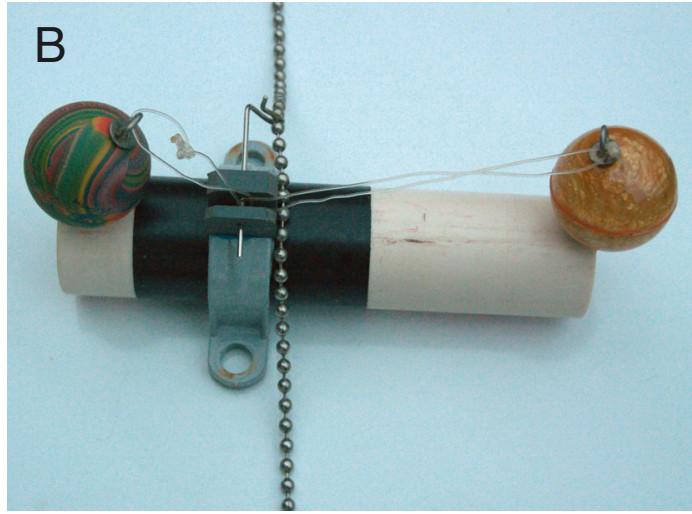

Fig. 3. (A) Benthic lander and (B) close-up view of one of the 14 Niskin-style chambers. The lander was designed for this project by T. G. Wolcott at North Carolina State University to collect 14 independent water samples simultaneously without mixing the water column

near-bottom light levels to determine whether higher levels of nutrients were available near the sea floor when light levels fell below $1 \%$ of surface PAR, depths where the less motile majority of phytoplankton are poorly represented.

\section{Biophysical model}

\section{STELLA framework}

The effect of small changes in location and distribution of nutrients in the water column on cellular growth and reproduction of $K$. brevis was tested using a biophysical simulation model constructed with STELLA (Systems Thinking for Education and Research; ISEE). STELLA provides a graphical model-building interface to follow a single process, in this case cellular swimming behavior, by visually defining causal relationships among model parameters (see the Appendix). The underlying model equations are then built automatically. The effect of variations in each parameter, as well as their relative importance for altering the main process, can be compared by using incremental changes in successive modeling runs. The power of the STELLA tool is to identify the effect of each individual factor on the experimental process (sensitivity analysis) and thus progressively simplify the model. The graphical format then gives an intuitive understanding of how small changes in some factors could result in important behavioral changes. 


\section{STELLA cellular model}

To regulate vertical swimming behavior and consequent exposures to light and nutrients (Kamykowski \& Yamazaki 1997, Yamazaki \& Kamykowski 2000), the 1-D spatial model relies on the calculation of internal pools of nutrients and photosynthate (Kamykowski et al. 1998a). The change in vertical position at each time step is calculated using 2 factors: time of day, governing vertical direction moved, and the current relative fullness of cellular $\mathrm{C}$ and $\mathrm{N}$ pools, governing speed and thus distance moved per time step (for model details, see the Appendix). Using the cell division rate and the migration height away from the benthos as the response variables, we determined the minimum thickness of a near-benthic nutrientenriched layer at depths from 20 to $60 \mathrm{~m}$, the minimum nutrient concentration from nitrogen compounds, $[N]$, needed for each nutrient layer thickness, and the importance of the nutrient distribution within the layer, for maintaining benthically oriented behavior.

\section{Modeled water column trials}

To determine the minimum nutrient distributions necessary to sustain a benthic population of cells, a minimum cellular division rate was first selected, above which a population was considered self-sustaining. Under nutrient replete conditions, $K$. brevis typically reproduces by fission at a rate of 0.3 divisions $\mathrm{d}^{-1}$, as in our model. Division rates for $K$. brevis in numerous studies have varied from 0.94 (Loret et

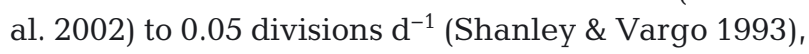
but tests specifically for a minimum division rate in natural environmental conditions have not been done. As potential populations of $K$. brevis surviving near the benthos may encounter conditions that are both light- and nutrient-limiting during different hours of a diel cycle, we selected a conservative minimum growth rate of 0.07 divisions $\mathrm{d}^{-1}$. This rate exceeded the minimum rates mentioned above, so was considered sufficient to sustain the population for the purposes of our experiments.

The minimum nutrient requirements for population persistence along the WFS were determined by modeling the effects of $\mathrm{NO}_{3}{ }^{-} / \mathrm{NO}_{2}{ }^{-}$levels (ranging from 0.1 to $10 \mu \mathrm{M}$ ) on division rate and the migration height up from the benthos. Enriched nutrient concentrations adjacent to the sediment-water interface were simulated and both the vertical extent of the $\mathrm{NO}_{3}{ }^{-} / \mathrm{NO}_{2}{ }^{-}$layer from the sediment (the nutrient layer thickness) and the concentration of those nutrients within the layer were varied, using ranges of 1 to $3 \mathrm{~m}$ for thickness, in $0.5 \mathrm{~m}$ increments, and nutrient concentrations in the layer of $0.1,0.5,1,2,5$, or $10 \mu \mathrm{M}$. Because maximum near-benthic light levels diminish as the water column deepens offshore, each of these nutrient concentrations was tested at depths of 20 to $60 \mathrm{~m}$, using $10 \mathrm{~m}$ increments, in conditions where $1 \%$ surface PAR uniformly penetrates to $\sim 22 \mathrm{~m}$ across the modeled shelf. All simulations were initialized with the dark-adapted, newly divided daughter cell containing half of the carbon and nutrients of the parent cell: $45 \mathrm{pmol} \mathrm{C}$ and $10 \mathrm{pmol} \mathrm{N}$.

The distributions of nutrients within the 1 to $3 \mathrm{~m}$ thick near-benthic layers were also altered from uniform concentrations to gradients that decreased (linearly or exponentially) with increased distance from the benthos, using ranges of either 3 to $0.1 \mu \mathrm{M}$ or 10 to $0.1 \mu \mathrm{M}$. Finally, a randomly-varying nutrient concentration within the enriched layer was specified, using 0 to 4 and 0 to $10 \mu \mathrm{M}$ nutrient ranges, to mimic the effect of small-scale turbulent advection from a benthic nutrient source. The division rates and vertical migration heights were used to determine the minimum nutrient concentration and maximum bottom depth at which a population of $K$. brevis with benthic orientation could be sustained.

\section{Mimicking plankton: ABLE}

\section{ABLE description}

The Autonomous Behaving Lagrangian Explorer (ABLE), designed by Dr. Tom Wolcott (unpubl.), is a biomimetic robotic drifter that senses in situ environmental stimuli (e.g. variations in PAR, pressure, salinity, or temperature) and can be programmed to respond to these cues with vertical migration behavior like that of the planktonic organism of interest. In the case of $K$. brevis, the ABLE bases its vertical migrations on continuous calculations of the fulfillment of internal cellular needs under in situ conditions, and modulation of the swimming velocity in a biologically realistic way.

\section{Quarry deployment}

To assess whether vertical swimming behavior of $K$. brevis would remain benthically oriented in response to changes in benthic nutrient sources under natural light conditions, 6 ABLEs were deployed 
simultaneously, with 3 replicate deployments, in a flooded rock quarry (Rolesville, NC) for 6 to $12 \mathrm{~d}$, to span periods longer than the expected time to the next cellular division. ABLEs were tested in June, July, and September of 2008, corresponding with the light conditions during the BenDiM cruises. The light attenuation coefficient $(k=0.26)$ was within the range found in the GOM ( $k=0.04$ to 0.4$)$ and the water column depth $(17 \mathrm{~m})$ was only a few meters deeper than the expected migration amplitude of $K$. brevis. The ABLEs logged the driving variables (diel time, in situ light and temperature) and their responses to those drivers (their vertical migration profiles, the calculated concentrations of nutrients they encountered, fullness of C- and N-pools, and cellular division rates). The ABLEs were programmed to calculate changes in their $\mathrm{N}$ and $\mathrm{C}$ pools based on in situ conditions, and modify vertical movement, using the same formulas, parameter constants, and rules for division as in the STELLA model. To prevent drifting into quarry walls, ABLEs were attached to rings sliding freely on taut vertical cords.

To determine whether, after upwelling has occurred offshore, the appearance of blooms is behaviorally induced or a result of physical water processes, the ABLEs were programmed to 'encounter' one of 2 different nutrient regimes as they migrated downward. To simulate benthic flux, the ABLEs were programmed to encounter $0 \mu \mathrm{M}[\mathrm{N}]$ in the water column and a uniform concentration of $10 \mu \mathrm{M}$ [N] extending $0.5 \mathrm{~m}$ from the sediment. To simulate the upwelling conditions seen just before many blooms, ABLEs were programmed to encounter $0.1 \mu \mathrm{M}[\mathrm{N}]$ in the water column and an increasing concentration as a function of decreasing temperature below $11 \mathrm{~m}$. The latter was governed by $[\mathrm{N}]=T_{\mathrm{m}} C-T_{\mathrm{C}} C$, where $C$ is the cellular carbon content, $T_{C}$ is the water temperature below the thermocline $\left({ }^{\circ} \mathrm{C}\right)$ and $T_{\mathrm{m}}$ is an arbitrary value above the maximum expected temperature at the top of the thermocline. In the conditions in the quarry, where the thermocline was at about $11 \mathrm{~m}$ depth, this resulted in a gradient of $>0.1$ up to a theoretical maximum of $\sim 6 \mu \mathrm{M}[\mathrm{N}]$. The vertical migrations of ABLEs under simulated field conditions were compared with output of computer models simulating the same conditions. If a benthic nutrient source results in bottom oriented vertical migration of $K$. brevis (models or mimics), and nutrients from such a source in the GOM are sufficient to maintain growth in that benthically oriented population, then they could sustain a population of cells that could subsequently seed a bloom under upwelling conditions.

\section{RESULTS}

\section{Water column sampling}

Near-bottom profiler

Average near-bottom concentrations of $\mathrm{NO}_{3}{ }^{-} / \mathrm{NO}_{2}{ }^{-}$ measured on the WFS in the GOM were higher at the $40 \mathrm{~m}$ isobath, where light levels were $\sim 3.2 \%$ surface $\mathrm{PAR}$, than at 30 or $20 \mathrm{~m}$ isobaths, where light was $\sim 8$ and $22 \%$ surface PAR, respectively. In near-bottom water collected by our micro-samplers, $\mathrm{NO}_{3}{ }^{-} / \mathrm{NO}_{2}{ }^{-}$ concentration varied from $<0.1 \mu \mathrm{M}$ to $7 \mu \mathrm{M}$ with high variability between successive samples spaced at 10 to $20 \mathrm{~cm}$ intervals from the bottom. No discernible gradient in nutrients with increasing distance from the benthos was evident in the samples from any of the $2 \mathrm{~m}$ vertical transects. Average $\mathrm{NO}_{3}{ }^{-} / \mathrm{NO}_{2}{ }^{-}$values at the 40,30 , and $20 \mathrm{~m}$ isobaths were $2.129 \pm 0.15,0.93 \pm$ 0.15 , and $1.376 \pm 0.17 \mu \mathrm{M} \pm \mathrm{SE}$, respectively. No data were collected at one of the 3 intended $30 \mathrm{~m}$ isobath sites, and one of the 3 stations at the $40 \mathrm{~m}$ isobath was sampled twice at different times during the cruise.

\section{CTD sampling}

Average $\mathrm{NO}_{3}{ }^{-} / \mathrm{NO}_{2}{ }^{-}$, using ISUS-analyzed Niskin water samples from vertical profiles along 2 crossshelf transects (Fig. 4E) put the nutrient distributions into the context of the whole water column (Fig. 4A) and showed a pattern similar to that found in the benthic lander samples from the bottom meter of the water column (Fig. 5): $<0.3,1.5,0.89,3.4$, and $6.2 \mu \mathrm{M}$ at $20,30,35,40$ to 50 , and $60 \mathrm{~m}$ bottom depths, respectively. Although these measurements were not identical to the average values from the benthic landers, they fell well within the range of individual lander samples for each isobath. The upper bound of the near-benthic nutrient layer could not be determined precisely from Niskin samples, but the layer seemed to increase in both thickness (Fig. 4A) and $\mathrm{NO}_{3}{ }^{-} / \mathrm{NO}_{2}{ }^{-}$ (Fig. 4F) as bottom depth increased, from 2 to $5 \mathrm{~m}$ and $1.54 \mu \mathrm{M}$ in the bottom $2 \mathrm{~m}$ at the $30 \mathrm{~m}$ isobath to $>15 \mathrm{~m}$ and $8.92 \mu \mathrm{M}$ in the bottom $2 \mathrm{~m}$ at the $65 \mathrm{~m}$ isobath. Between the 20 to $35 \mathrm{~m}$ isobaths, chl a levels by in vivo fluorescence (an indicator of phytoplankton biomass) (Fig. 4C,G) were 1 to $4 \mu \mathrm{g} \mathrm{l}^{-1}$ near the benthos. From the 40 to $65 \mathrm{~m}$ isobaths, chl a levels were $<0.7 \mu \mathrm{g} \mathrm{l}^{-1}$. The calculated Brunt-Väisälä frequency (Fig. 4D) maximum, along with temperature and salinity gradients, indicated a stratification of surface and deeper water typical of non-bloom periods. 

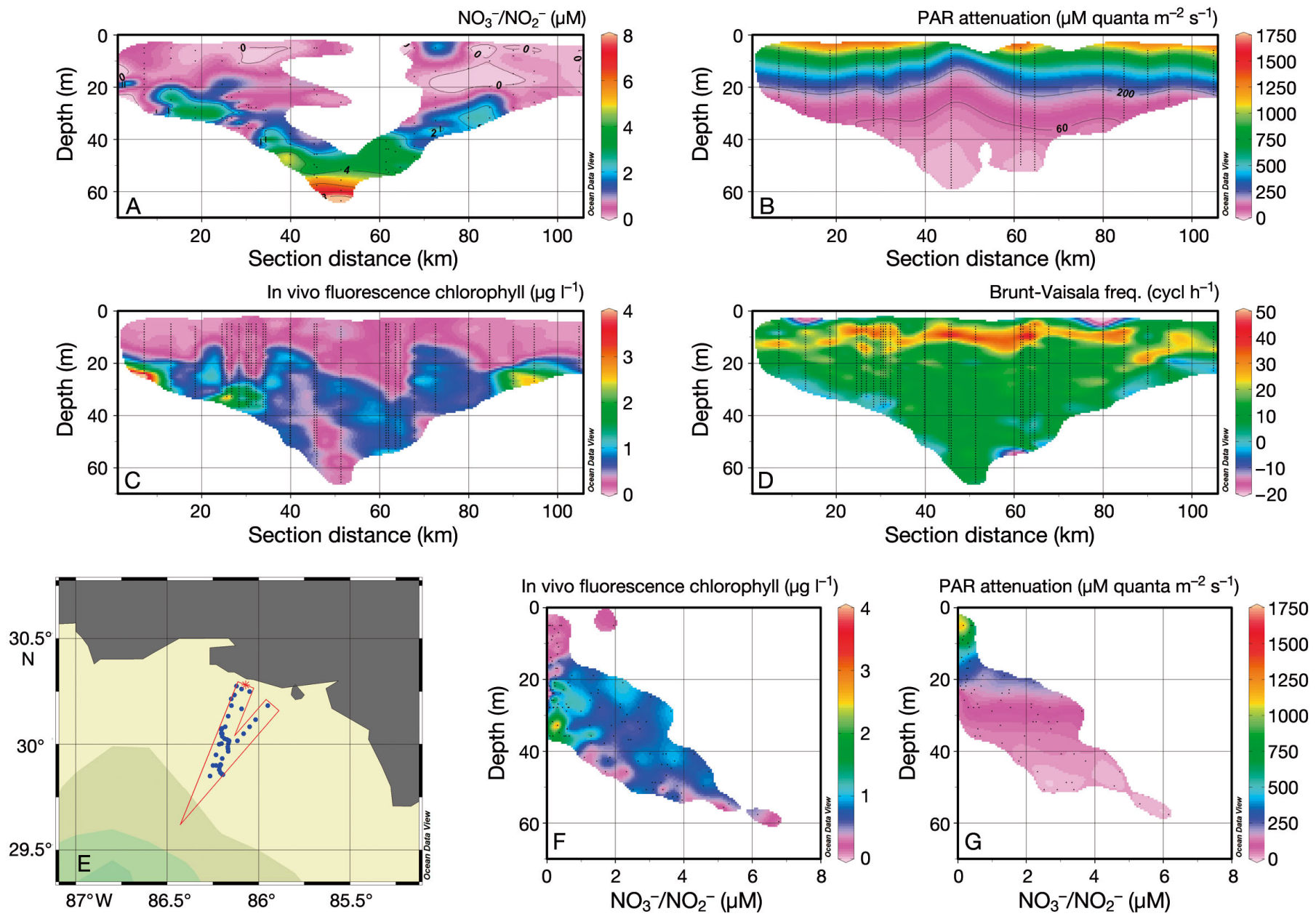

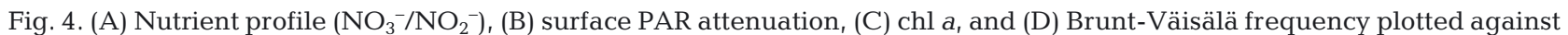
depth, as well as (F) chl a and (G) PAR plotted against nutrients, of samples taken on 2 cross-shelf transects conducted in July 2009 off Destin, FL. (E) Section distance is the distance along the transect, beginning near shore on the western leg, moving offshore to the farthest sample point, then returning near shore along the eastern leg. Plots were generated using Ocean Data View (Schlitzer 2012)

\section{Biophysical model}

The STELLA model was used to determine, for various nutrient layer thicknesses, the minimum nutrient concentration needed to sustain the minimum growth rate allowing persistence of a population (Fig. 6) using a representative, species-specific nutrient uptake capability. When $k=0.1 \mathrm{~m}^{-1}$ with a uniform layer of enriched nutrients near the benthos, growth rates of 0.07 divisions $\mathrm{d}^{-1}$ were not sustained at depths below $50 \mathrm{~m}$ for any of the tested concentrations and nutrient distribution profiles. Population growth occurred with nutrient concentrations $\geq 0.5 \mu \mathrm{M}$ for depths $\leq 50 \mathrm{~m}$ (when $>0.7 \%$ surface PAR reached the sediment) if nutrients extended through a $3 \mathrm{~m}$ layer from the benthos. If nutrient concentrations were $\geq 1 \mu \mathrm{M}$ throughout a nutrient layer $\geq 1.5 \mathrm{~m}$ thick, growth occurred as deep as $45 \mathrm{~m}$ (1.1\% surface PAR at the sediment). Growth was sustained at $50 \mathrm{~m}$ by a nutrient layer with this same $1.5 \mathrm{~m}$ thickness, but only if the concentration throughout was $\geq 5 \mu \mathrm{M}$, a concentration rarely observed on the oligotrophic GOM shelf other than in a study conducted in conjunction with the present one (McCulloch et al. 2013). A growing population was not maintained when bottom depth was $60 \mathrm{~m}(0.25 \%$ surface PAR $)$ unless the nutrient layer extended $\geq 6 \mathrm{~m}$ from the bottom.

When the nutrient concentration within the enriched layer was either a linear gradient or randomly varying between 0.1 and $10 \mu \mathrm{mol} \mathrm{NO}_{3}{ }^{-} / \mathrm{NO}_{2}{ }^{-}$(see Appendix), the growth rates were similar to those in a uniform layer with the same average nutrient concentration (Fig. 7). At the $30 \mathrm{~m}$ isobath, for example, where light was $5 \%$ surface PAR, the growth rate 


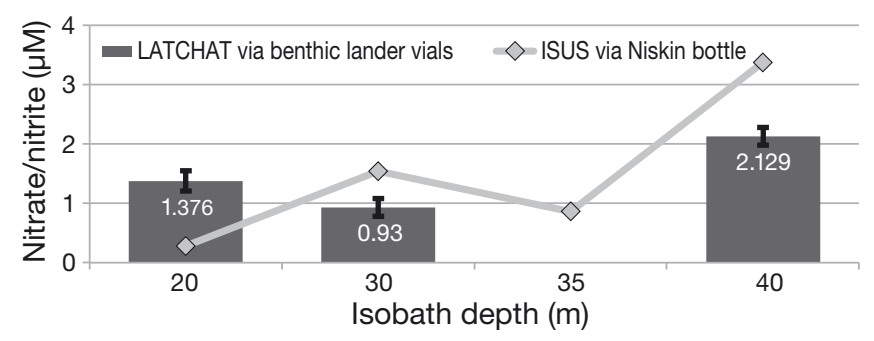

Fig. 5. Average $\mathrm{NO}_{3}{ }^{-} / \mathrm{NO}_{2}{ }^{-}$concentration (bars) measured at 3 different isobaths off Destin, FL, collected using a benthic lander during a cruise in July 2009 and analyzed in the laboratory using a Lachat Autoanalyzer. Samples were also collected at similar depths (diamonds) but different sites via Niskin bottles and analyzed on ship using an ISUS sensor. The Niskin/ISUS measurements fall within the range of the individual lander measurements. Black bars $=\mathrm{SE}$

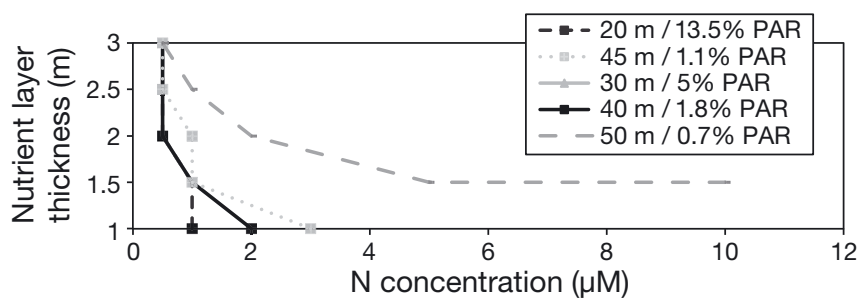

Fig. 6. Modelled minimum nutrient layer thicknesses and nutrient concentrations that result in Karenia brevis cellular division of $>0.07$ divisions $\mathrm{d}^{-1}$ for 5 different bottom depths, assuming the presence of a near-bottom nutrient layer. For this experiment, the light attenuation coefficient $k=0.1$, a value typical for the West Florida Shelf in the Gulf of Mexico. Note that the lines for 30 and $40 \mathrm{~m}$ completely overlap increased with each increase in average nutrient concentration within a $1 \mathrm{~m}$ thick nutrient layer regardless of whether the distribution was constant, linearly decreasing, or random. As the thickness of the nutrient layer increased at this depth, the division rate differed by a day between different nutrient distributions. When light levels near the benthos were $0.7 \%$ of surface PAR, as at the $50 \mathrm{~m}$ isobath in the model, growth above the 0.07 division $\mathrm{d}^{-1}$ threshold occurred in an enriched layer with uniform $[\mathrm{N}]$ when it was $\geq 1.5 \mathrm{~m}$ thick, but it needed to be $\geq 2 \mathrm{~m}$ thick if $[\mathrm{N}]$ was variable as it is more representative of the natural heterogeneity of nutrients in the water column. At $60 \mathrm{~m}$, where light is $0.25 \%$ surface PAR, the population did not have enough light to maintain benthic orientation and instead migrated upward, becoming a surface-oriented population.

To determine causal relationships on growth rate when $[\mathrm{N}]$ had little independent effect, growth rate was analyzed in a multivariate matrix for correlations with the hours per day that our modeled phytoplankton were exposed to both light and nutrients, depth (along with the corresponding light exposure), the thickness of the nutrient layer, the concentration of the nutrients, and the distribution pattern of those nutrients. The strongest correlation (Fig. 8) for constant nutrient concentrations (0.75) was between the growth rate and time spent within a nutrient rich layer. Weaker correlations existed between growth rate and nutrient layer thickness (0.50) and bottom depth $(-0.70)$, but was not significant between growth rate and nitrogen concentration (0.23). If linearly decreasing and randomly distributed concentrations were included in the comparison for the 20 to $50 \mathrm{~m}$ isobaths, then the linear concentrations showed the greatest correlations, 0.66 and -0.66 for nutrient layer depth and bottom depth respectively, whereas nutrient exposure time lost significance since it did not differ between the 2 different concentration profiles. For randomly distributed concentrations, the effect of bottom depth became the primary correlation with division rate $(-0.75)$ followed by nutrient layer depth (0.52).

\section{Mimicking plankton: ABLE}

Nutrient effects given natural light changes

Benthically oriented migration occurred for multiple ABLE devices under natural
Fig. 7. Karenia brevis population growth rates (divisions $\mathrm{d}^{-1}$ ) simulated for a variety of nutrient distributions and bottom depths. Within the nutrient layer, the tested constant nutrient concentrations, randomly variable concentrations and linearly varying concentrations are averaged together for each nutrient layer depth at each isobath 
Fig. 8. Correlation matrix of modeled Karenia brevis populations, showing the correlation between the minimum values of several parameters that resulted in population sustainability by comparing population growth rate (divisions $\mathrm{d}^{-1}$ ) to the minimum values for nutrient concentration, light exposure (bottom depth), nutrient layer thickness, and hours exposed to nutrients per day. Grey areas indicate density ellipses; the ellipses for strong correlations will appear increasingly thin and more diagonal as the correlation approaches $1 /-1$

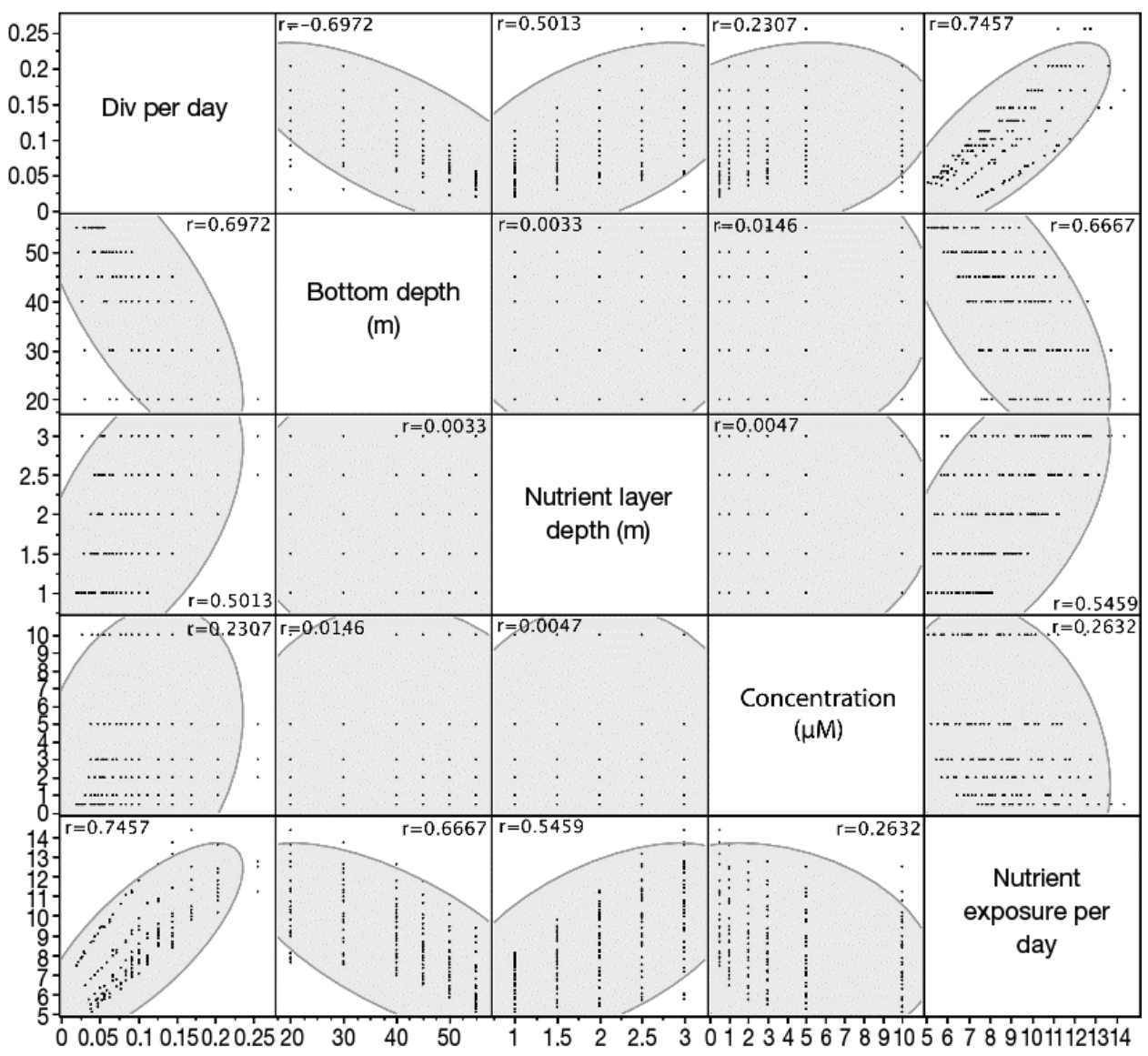

light conditions in a quarry when we compared deployments of 8 ABLEs sensing upwelled nutrients to 6 ABLEs detecting a thin near-benthic nutrient layer (Fig. 9). When nutrients were available only within $0.5 \mathrm{~m}$ of the bottom of the quarry at $10 \mu \mathrm{M}$ concentrations, cells remained benthically oriented with a diel vertical migration (DVM) centered around an average depth of $12.8 \mathrm{~m}$ during the cellular lifespan and a predicted average depth of $13.4 \mathrm{~m}$ using the assumption that cells continued to accumulate photosynthate and nutrients with the same levels of nutrient and light exposure until cellular division. ABLE deployed with the temperature-dependent upwelled nutrient scenario, with low levels of nutrients throughout the water column and an elevated concentration in the bottom $5 \mathrm{~m}$ of the water column, had a DVM with an average depth of $8.9 \mathrm{~m}$, and several units reached the surface after the first 'cellular division'. Those 'cells' had a net positive uptake of nutrients throughout the water column from the background $0.1 \mu \mathrm{M} \mathrm{NO}_{3}{ }^{-} / \mathrm{NO}_{2}{ }^{-}$concentration, causing the units to migrate upward to within $4 \mathrm{~m}$ of the surface and to utilize only the top of the deep nutrient-enriched layer.

\section{Population persistence}

Growth rates calculated by ABLEs in the $5 \mathrm{~m}$ thick, low-concentration nutrient scenario averaged 0.23 divisions $\mathrm{d}^{-1}$ and 'cell division' often occurred twice in the course of the deployment (Fig. 10). In the $0.5 \mathrm{~m}$ thick nutrient layer scenario, only one of the deployments resulted in cells that did not divide within the 0.07 divisions $d^{-1}$ threshold. Deployment durations were shorter than cellular division times for ABLEs simulating a near-benthic nutrient layer, so the division rate and time of exposure to nutrients were projected based on a predictable level of exposure to light and nutrients for each deployment. Incorporating the light attenuation, depth, and nutrient scenarios into the STELLA model resulted in an average depth of $11.9 \mathrm{~m}$ for the benthic scenario and $9.46 \mathrm{~m}$ for the upwelled nutrient scenario, with growth rates and vertical behavior similar to the ABLE profiles. The ABLEs mimicking dinoflagellates in the quarry spent less time in the benthic nutrient layer than model dinoflagellates in the equivalent STELLA scenario; the sensors used in nutrient calculations detected conditions that would have resulted in a 

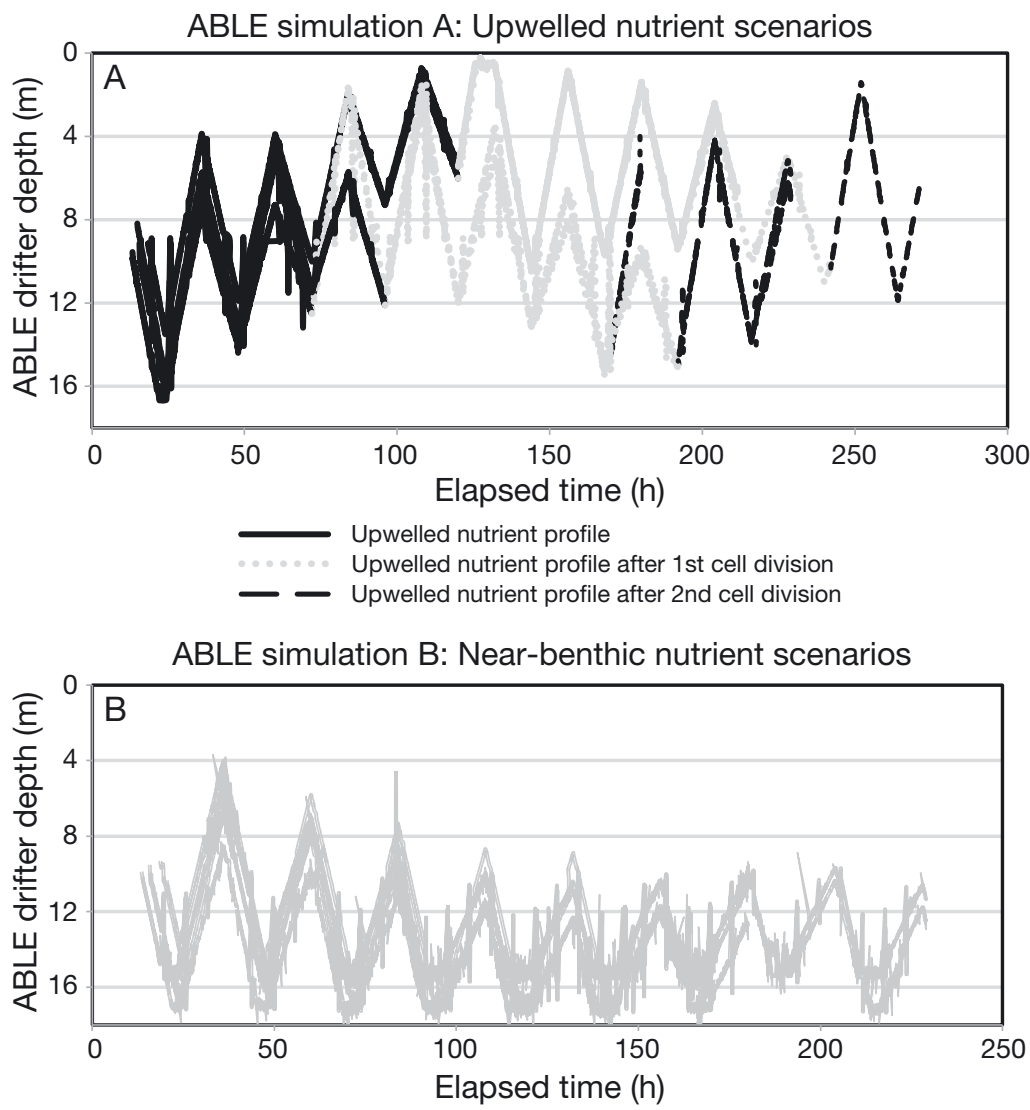

Fig. 9. Comparison between diel vertical migrations (DVM) of individual Autonomous Behaving Lagrangian Explorer (ABLE) biomimetic robots (simulating Karenia brevis DVM) in a rock quarry of $17 \mathrm{~m}$ depth under (A) nutrient conditions indicative of upwelling, and (B) severe nutrient limitation (near-benthic nutrients), revealing responses resulting in either surface- or benthically-oriented DVM. The flattened sections at the bottom of several profiles indicate periods when the ABLE encountered the bottom of the quarry. Differences in bottom depth between profiles are real as the quarry bottom was uneven. The periodic sharp changes in depth in some of the profiles correspond with instrument-related buoyancy control difficulties and not to planktonic migration behaviors nutrient exposure time of 1.9 to $3.1 \mathrm{~h} \mathrm{~d}^{-1}$ during the quarry experiments. In addition, 2 of these benthically oriented ABLEs malfunctioned because the sensor upon which the nutrient calculations depended did not operate as designed, causing them to have an artificially low 'nutrient uptake' period. A simultaneous light sensor malfunction on one of these ABLEs caused the simulated cellular respiration to exceed cell resource 'uptake', so the cell had a net loss of cellular resources during deployment. These data were not excluded, unlike those from the other units that failed to operate as programmed through hardware failure, because they demonstrate the effect of extreme nutrient limitation on growth and migration. Difficulties arising from malfunctions were a natural hazard of using prototypes of an instrument still under development.

\section{DISCUSSION}

\section{Population persistence}

Multiple theories have been proposed for the formation and sustainability of offshore Karenia brevis blooms, but little focus has been placed on how and where the cells that act as seed populations for blooms are subsisting during non-bloom periods. While blooms of some dinoflagellate species initiate after the excyst-

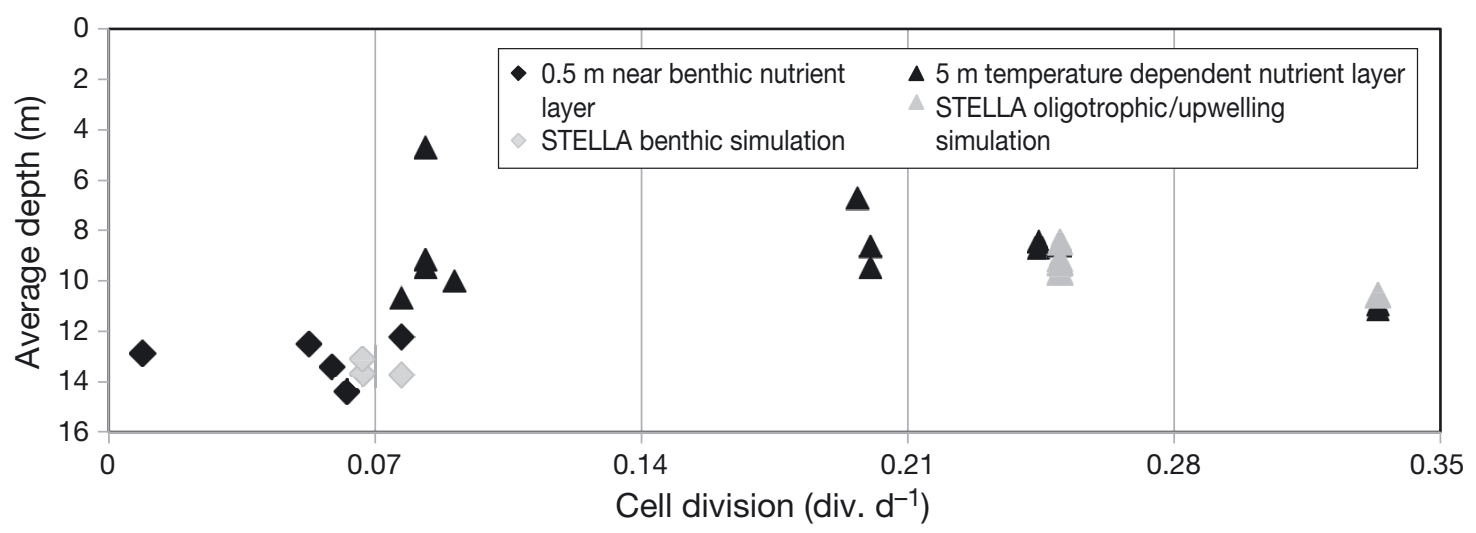

Fig. 10. Comparison of average migration depths and cellular division rates for simulated $K$. brevis cells in a rock quarry of $17 \mathrm{~m}$ depth using ABLE biomimetic robots, along with a modelled (Systems Thinking for Education and Research; STELLA) simulation using the same nutrient and light conditions. One nutrient scenario was typical of a stratified water column in summer (diamonds), and the other of upwelling in fall (triangles) 
ment of resting cysts that previously fell to the sediment during extreme unfavorable conditions (Prakash 1967, Steidinger 1975), K. brevis does not appear to have a resting cyst phase (Persson et al. 2013) from which blooms could initiate. Based on the behavior of $K$. brevis in our STELLA model and with ABLE in our quarry experiments, we suggest that a near-benthic subpopulation is a plausible alternative source for some red tide blooms. The presence or absence of such near-benthic subpopulations in particular locations could be governed by the distribution of nutrients within the lower region of the water column. In a system with nutrients randomly distributed within a near-benthic layer, near-benthic light levels are the primary factor regulating division rate; if nutrients decrease linearly away from the sediment-water interface, the nutrient layer thickness and near-benthic light become equally important; and if nutrient levels are constant throughout a near-benthic layer, the time a cell spends within the nutrient layer is the strongest predictor of growth.

On the northwest coastal shelf of Florida in 2009 during July, a month when blooms are uncommon, $\mathrm{NO}_{3}{ }^{-} / \mathrm{NO}_{2}{ }^{-}$in the GOM exceeded levels required in models for populations of benthically oriented $K$. brevis to subsist. At a bottom depth of $50 \mathrm{~m}$, when light averaged $0.52 \%$ of surface PAR, the STELLA model showed that a population could persist given a benthic nutrient layer $\geq 3 \mathrm{~m}$ thick that contained $[\mathrm{N}] \geq 0.5 \mu \mathrm{M}$. Under these same light attenuation conditions in the GOM, we measured a layer containing $\geq 0.5 \mu \mathrm{M} \mathrm{NO}{ }_{3}^{-} / \mathrm{NO}_{2}{ }^{-}$extending to at least $15 \mathrm{~m}$ from the benthos. In general, nutrients near the benthos extended farther from the sediment as bottom depth increased beyond $35 \mathrm{~m}$, where light is $2.5 \%$ of surface PAR. Shallower than $35 \mathrm{~m}$, nearbottom concentrations averaged between 1 and $2 \mu \mathrm{mol}$, with the lowest values occurring between 30 and $35 \mathrm{~m}$ isobaths in both the benthic lander and Niskin bottle samples. Chl a profiles also showed an increase to as much as $3.0 \mu \mathrm{g} \mathrm{l}^{-1}$ between 30 and $35 \mathrm{~m}$, coinciding with the decrease in $\mathrm{NO}_{3}{ }^{-} / \mathrm{NO}_{2}{ }^{-}$ near the benthos, indicating that the decrease in $\mathrm{NO}_{3}{ }^{-} / \mathrm{NO}_{2}{ }^{-}$is likely to be biologically related, perhaps through utilization by phytoplankton species other than K. brevis. K. brevis cells did not dominate the phytoplankton biomass in this region, as expected from their relatively slow growth rate under nutrient-replete conditions (Walsh et al. 2001), but were instead found near the benthos below the $10 \%$ of surface PAR threshold, at bottom depths of $35 \mathrm{~m}$ to the end of the transect at $65 \mathrm{~m}$ (McCulloch et al. 2013).
Near-benthic nitrate and nitrite appeared to be less available in the near-benthic layer along this same transect during the summer-fall transition, when mixing events may redistribute nutrients throughout the water column and blooms are frequently detected (Fig. 11). During the BENDIM2 cruise in October 2008 (Kamykowski et al. 2013), $\mathrm{NO}_{3}{ }^{-} / \mathrm{NO}_{2}{ }^{-}$in Niskin bottle samples showed a distribution between 1.48 and $1.89 \mu \mathrm{M}$ throughout the water column after the passage of the wind event. Light sufficient to saturate growth in dark-adapted cells penetrated to an average of $17.4 \mathrm{~m}(k=0.29)$, and STELLA simulations performed with this light attenuation value suggested that for bottom depths $\geq 26 \mathrm{~m}$ populations would persist only if sub-euphotic zone nutrients extended to within 4 or $5 \mathrm{~m}$ of the region into which light penetrated. High light attenuation made the formation of a benthic subpopulation unlikely according to our model because, when isobaths were deeper than $20 \mathrm{~m}$, populations either became surface-oriented due to light limitation or did not attain the minimum growth rate.

Contrary to model predictions, gyroxanthin-containing dinoflagellates, a group which includes $K$. brevis, were detected near the benthos along these same transects in significant numbers, not only near the $20 \mathrm{~m}$ isobath as predicted, but also in lower numbers near the benthos down to $50 \mathrm{~m}$ (Grabowski 2010). A partial explanation is offered by the ability of $K$. brevis cells to migrate into interstitial spaces between sediment grains (Sinclair \& Kamykowski 2008), where higher nutrient concentrations may be available (Sinclair et al. 2006b). K. brevis also has the ability to utilize organic forms of $\mathrm{N}$ (Wilson 1966), exhibiting higher growth rates than when using inorganic forms (Shimizu et al. 1995). Under low-light conditions, their maximum uptake rates (in $\mathrm{pmol} \mathrm{h}^{-1}$ ) increased 2- to 3-fold, to $0.77\left(\mathrm{NH}_{4}{ }^{+}\right)$and 0.51 (Urea) as opposed to $0.20 \mathrm{pmol} \mathrm{N}$ cell $^{-1} \mathrm{~h}^{-1}$ for $\mathrm{NO}_{3}{ }^{-}$(Sinclair et al. 2009). On the October 2008 cruise, an average of $0.44 \mu \mathrm{M} \mathrm{NO}_{3}{ }^{-}$and $10.56 \mu \mathrm{M} \mathrm{NH}_{4}{ }^{+}$were detected in porewater samples collected from $0.5 \mathrm{~cm}$ below the sediment surface at one sampling site (G. Sinclair pers. obs.). Another factor that may contribute to persistence of $K$. brevis under severe nutrient limitation is that it can also enhance its dark uptake of $\mathrm{N}$ to nearly daylight rates subsequent to low-nutrient exposure (Sinclair et al. 2006a). Furthermore, when a $K$. brevis cell near the benthos receives less (Sinclair \& Kamykowski 2006) than the compensation irradiance of $0.3 \%$ surface PAR (Shanley 1985, Shanley \& Vargo 1993), it may become phagotrophic. Mixotrophy, already suggested as a potentially important 

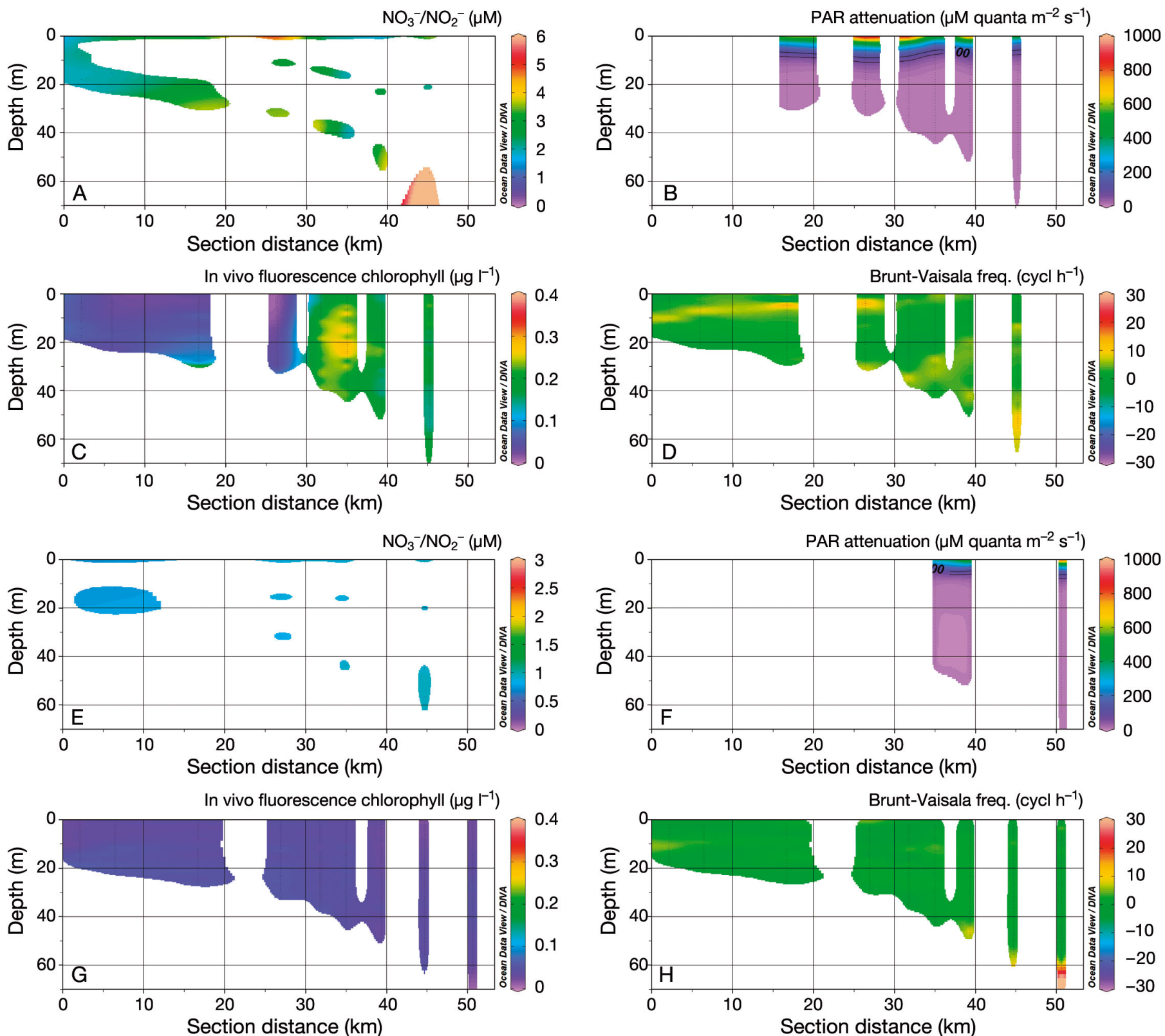

Fig. 11. Changes in water column structure, distribution of phytoplankton biomass, and nutrient concentrations (A-D) before and $(\mathrm{E}-\mathrm{G})$ after a wind event ( 3 d interval), collected from a cross-shelf transect near Destin, FL, during October 2008. Note the scale difference for the color bar between $(\mathrm{A})$ and $(\mathrm{E})$

mechanism for nutrient acquisition for harmful algal blooms in high-nutrient, low-light environments (Burkholder et al. 2008), has been detected in K. brevis, when they ingested Synechococcus in a laboratory experiment (Jeong et al. 2005), and suggested or detected for a variety of prey in numerous other dinoflagellate species (summarized in Stoecker 1999, Burkholder et al. 2008). Such additional nutrient sources and changes to uptake rates could be included to strengthen the realism of future models. These behaviors may be the alternatives for $K$. brevis in place of the formation of resting cysts and be superior survival strategies as bloom-favorable conditions could occur at any time of year in the GOM.

Benthic lander samples did not reveal a nutrient gradient above the sediment that could cue oriented swimming responses (as observed in other dinoflagellates; Ikegami et al. 1995). Instead, they indicated patchiness of nutrient availability, with nitrogen concentrations changing by as much as $4.6 \mu \mathrm{mol}$ over a 10 to $20 \mathrm{~cm}$ depth increment. If these conditions are typical for the GOM, then K. brevis cannot be rely- 
ing on a 'nutrient taxis,' swimming directionally in response to a gradient. The individual migration responses of $K$. brevis cells to encounters with this patchy nutrient distribution may partially explain their nocturnal dispersion throughout the lower water column (Kamykowski et al. 1998a,b, Sinclair 2005), rather than concentration in a discrete layer near the benthos, as would be expected from a tactic migration response to a gradient. A near-benthic aggregation, however, was noted during the ECOHAB 2000 cruise (Sinclair \& Kamykowski 2008). The patchiness of $\mathrm{NO}_{3}{ }^{-} / \mathrm{NO}_{2}{ }^{-}$was not detected in the samples collected via Niskin bottles from CTD casts, probably due to the averaging effects resulting from the much larger size of the bottles and the mixing effect from the vertical motion of the rosette during collection. Growth rate in our STELLA model did not correlate significantly with a patchy distribution of nutrients within the near-benthic layer (the 'random distribution' case), so our model predictions remain unchanged.

\section{Benthic versus surface orientation of migration}

For a potential near-benthic seed population to be maintained, nutrient limitation and a near-benthic nutrient supply within reach of accessible light are expected to define, respectively, the nearshore and offshore extents of the habitable range of that subpopulation. In these experiments, the simulated dinoflagellates were not programmed to migrate with any explicit reference to the bottom; instead, they maintained that benthic orientation by swimming behavior modulated solely by relative internal levels of photosynthate and nutrients $(\mathrm{C}$ and $\mathrm{N}$ ) required for growth. In our quarry simulation of a nearshore environment, we compared the reaction of $K$. brevis cells to 2 different sets of environmental conditions: nutrients restricted to a thin layer near the benthos, such as might be encountered during summer months in a stratified water column, and diffuse nutrients extending well up into the water column, such as might be encountered during the onset of upwelling in the fall. While the simulated $K$. brevis cells remained in the lower part of the water column if nutrients were restricted to the bottom $0.5 \mathrm{~m}$, this extreme nutrient limitation resulted in neither cellular division above our threshold of 0.07 divisions $\mathrm{d}^{-1}$, nor (consequently) population maintenance. Even using average rather than extreme nutrient conditions for this season, dinoflagellates grow $1 / 3$ as fast as many other species of co-occurring phytoplankton (van Dolah \&
Leighfield 1999, Walsh et al. 2001), so are not well suited to outcompete them in this nearshore region. At the other extreme, in offshore water when light levels fell below the minimum carbon uptake threshold for $K$. brevis, the ABLE migrated higher into the water column. Although a surface nutrient source was not included in ABLE programs, as in the STELLA model a subsequent encounter with any nutrient source near the surface caused the migrations of simulated $K$. brevis cells to become surface oriented.

The appearance of $K$. brevis blooms, originating 18 to $74 \mathrm{~km}$ offshore (Steidinger 1975), may be related to a transition of a near-benthic population to surface orientation as the nutrient conditions make a seasonal transition between states similar to the extremes tested in our quarry experiments. The unpredictability of these bloom occurrences may be related to the high variability in the availability of suitable near-benthic 'habitat' due to light attenuation. Our seed population in the STELLA model persisted at bottom depths of at least $50 \mathrm{~m}$ when $k=0.1 \mathrm{~m}^{-1}$ as it was in July 2009; this isobath occurs 26 to $145 \mathrm{~km}$ offshore, depending on the location along the WFS. Conversely, when $k=0.29 \mathrm{~m}^{-1}$ (as it was in October 2008) was used in the model, the $1 \%$ surface PAR penetrated to only $17.4 \mathrm{~m}$, so populations with a $2 \mathrm{~m}$ thick nutrient layer could survive only to $26 \mathrm{~m}$ bottom depths, or 4 to $35 \mathrm{~km}$ offshore. If a minimum of $3.5 \mathrm{~h}$ of time spent in a high nutrient region is required for growth during a downward migration, as in our STELLA model, we can determine that the $1 \%$ surface PAR must be available within $\sim 9 \mathrm{~m}$ of a highnutrient near-benthic layer for cells to maintain a growth rate above 0.07 divisions $\mathrm{d}^{-1}$. Benthically oriented cells carried with bottom water could encounter a broad range of conditions in the shelf of the GOM; so, being able to survive in very limiting conditions may be a critical advantage for $K$. brevis. Populations near the benthos can persist for several generations if transported into low-light strata. When transported onshore into nutrient rich, shallower, higher-light waters, surviving cells might later seed a bloom if they accumulate in frontal regions (Liu et al. 2001a, Janowitz \& Kamykowski 2006).

While surface-oriented $K$. brevis populations are well studied and a near-benthic subpopulation also has considerable evidence to support it, an additional third type of mid-water subpopulation may exist in deeper offshore water, with different implications for transport based on water column position. Aside from the near-benthic concentration, an additional elevated concentration of gyroxanthin-containing dinoflagellates was measured $\sim 12 \mathrm{~m}$ above the sedi- 
ment when the bottom depth $(42 \mathrm{~m})$ was well below the euphotic zone (Grabowski 2010). Similar aggregation at mid-depth was also noted in the STELLA model; in cases where near-benthic light became too limiting for growth but nutrients were also limiting, some cells moved up into the mid-water column and migrated between low light at the bottom of the euphotic zone and the top of a diffuse nutrientenriched layer extending several meters up from the benthos.

We suggest blooms can form when a subpopulation that has persisted deep in offshore shelf waters maintains a benthic-oriented DVM while being carried toward shore, with the deep water, under upwelling conditions. For a bloom to form and be transported shoreward, the $K$. brevis cells must increase in number with each successive generation, and the water layers through which they are migrating must be moving shoreward. As this subpopulation moves shoreward into shallower waters with lower nearbenthic nutrients and higher light, the migrational pattern will change from benthic- to surface-oriented near shore, exposing the cells to higher near-surface nutrients (Franks 1992). K. brevis cells will increase their growth rates in response to simultaneous exposure to both high nutrients and light exposure, may then be hydrodynamically accumulated in frontal regions (Janowitz \& Kamykowski 2006), and become a bloom. As the nascent bloom moves into the surface water, it becomes detectable by satellite and conventional sampling techniques.

Acknowledgements: We thank Donna Wolcott, Emerita at NC State University, Blake Schaeffer at the EPA, the crew of the R/V Pelican, Larry Brown at the NCSU Aquatic Center, Christian Lindqvist at Runecaster Design, and Arthur Güth at the University of São Paulo. Funding was partially provided by research grants from the EPA (R-82937001), NOAA (NA07FU0537) and the NSF (CNS-0509162 and 0726271).

\section{LITERATURE CITED}

Bein S (1957) The relationship of total phosphorus concentration in sea water to red tide blooms. Bull Mar Sci 7: 316-329

> Berdalet E, Latasa M, Estrada M (1992) Variations in biochemical parameters of Heterocapsa sp. and Olisthodiscus luteus grown in 12:12 light:dark cycles I. Cell cycle and nucleic acid composition. Hydrobiologia 238: 139-147

Bronk D, Sanderson M, Mulholland M (2004) Organic and inorganic nitrogen uptake kinetics in field populations dominated by Karenia brevis. In: Steidinger KA, Landsberg $\mathrm{JH}$, Tomas CR, Vargo GA and others (eds) Harmful algae 2002. Florida Fish and Wildlife Conservation Com- mission, Florida Institute of Oceanography and Intergovernmental Oceanographic Commission of UNESCO, St. Petersburg, FL, p 80-82

Burkholder JM, Glibert PM, Skelton HM (2008) Mixotrophy, a major mode of nutrition for harmful algal species in eutrophic waters. Harmful Algae 8:77-93

> Cullen J (1982) The deep chlorophyll maximum: comparing vertical profiles of chlorophyll a. Can J Fish Aquat Sci 39: 791-803

$>$ Cullen J, Horrigan S (1981) Effects of nitrate on the diurnal vertical migration, carbon to nitrogen ratio, and the photosynthetic capacity of the dinoflagellate Gymnodinium splendens. Mar Biol 62:81-89

Finucane JH (1964) Distribution and seasonal occurrence of Gymnodinium breve on the west coast of Florida, 1954-1957. US Fish Wildl Serv Spec Sci Rep Fish 487

Franks P (1992) Sink or swim: accumulation of biomass at fronts. Mar Ecol Prog Ser 82:1-12

Geesey M, Tester P (1993) Gymnodinium breve: ubiquitous in Gulf of Mexico waters. In: Smayda T, Shimizu Y (eds) Toxic phytoplankton blooms in the sea. Proceedings of the 5th International Conference on Toxic Marine Phytoplankton. Developments in Marine Biology, Vol 3. Elsevier, Amsterdam, p 251-255

Grabowski K (2010) Near bottom dinoflagellate populations on the northwest Florida Shelf. MS thesis, North Carolina State University, Raleigh, NC

> Hecky R, Kilham P (1988) Nutrient limitation of phytoplankton in freshwater and marine environments: a review of recent evidence on the effects of enrichment. Limnol Oceanogr 33:796-822

Heil C (1986) Vertical migration of Ptychodiscus brevis. MS thesis, University of South Florida, St. Petersburg, FL

Ikegami S, Iriai T, Kato J, Ohtake H (1995) Chemotaxis toward inorganic phosphate in the red tide alga Chattonella antiyua. J Plankton Res 17:1587-1591

Janowitz GS, Kamykowski D (2006) Modeled Karenia brevis accumulation in the vicinity of a coastal nutrient front. Mar Ecol Prog Ser 314:49-59

> Jeong HJ, Park JY, Nho JH, Park MO and others (2005) Feeding by red-tide dinoflagellates on the cyanobacterium Synechococcus. Aquat Microb Ecol 41:131-143

Kamykowski D (1974) Possible interactions between phytoplankton and semidiurnal internal tides. J Mar Res 32: 67-89

Kamykowski D, Yamazaki H (1997) A study of metabolisminfluenced orientation in the diel vertical migration of marine dinoflagellates. Limnol Oceanogr 42:1189-1202

Kamykowski D, Milligan EJ, Reed RE (1998a) Biochemical relationships with the orientation of the autotrophic dinoflagellate Gymnodinium breve under nutrient replete conditions. Mar Ecol Prog Ser 167:105-117

Kamykowski D, Milligan EJ, Reed R (1998b) Relationships between geotaxis/phototaxis and diel vertical migration in autotrophic dinoflagellates. J Plankton Res 20: 1781-1796

Kamykowski D, Pridgen KG, Morrison JM, McCulloch AA, Nyadjro ES, Thomas CA, Sinclair GA (2013) Cold front induced changes on the Florida panhandle shelf during October 2008. Cont Shelf Res 54:52-66

Kirkpatrick B, Fleming LE, Squicciarini D (2004) Literature review of Florida red tide: implications for human health effects. Harmful Algae 3:99-115

Liu G, Janowitz GS, Kamykowski D (2001a) A biophysical model of population dynamics of the autotrophic dino- 
flagellate Gymnodinium breve. Mar Ecol Prog Ser 210: 101-124

Liu G, Janowitz GS, Kamykowski D (2001b) Influence of environmental nutrient conditions on Gymondinium breve (Dinophyceae) population dynamics: a numerical study. Mar Ecol Prog Ser 213:13-37

Loret P, Tengs T, Villareal T (2002) No difference found in ribosomal DNA sequences from physiologically diverse clones of Karenia brevis (Dinophyceae) from the Gulf of Mexico. J Plankton Res 24:735-739

Magaña HA, Villareal TA (2006) The effect of environmental factors on the growth rate of Karenia brevis (Davis) G. Hansen and Moestrup. Harmful Algae 5:192-198

Mcculloch AA, Kamykowski D, Morrison JM, Thomas CJ, Grabowski Pridgen K (2013) A physical and biological context for Karenia brevis seed populations on the northwest Florida shelf during July 2009. Cont Shelf Res 63: 94-111

McKay L (2004) K. brevis cells—swimming speeds and internal cellular states over a range of temperatures and light intensities. PhD dissertation, North Carolina State University, Raleigh, NC

Odum HT, Lackey JB, Hynes J, Marshall N (1955) Some red tide characteristics during 1952-1954. Bull Mar Sci Gulf Caribb 5:247-258

Persson A, Smith BC, Morton S, Shuler A, Wikfors GH (2013) Sexual life stages and temperature dependent morphological changes allow cryptic occurrence of the Florida red tide dinoflagellate Karenia brevis. Harmful Algae 30: $1-9$

Prakash A (1967) Growth and toxicity of a marine dinoflagellate, Gonyaulax tamarensis. J Res Fish Board Can 24

Schlitzer R (2012) Ocean Data View 4. http://odv.awi.de

Shanley E (1985) Photoadaption in the red tide dinoflagellate Prychodiscus brevis. University of South Florida, Tampa, FL

Shanley E, Vargo G (1993) Cellular composition, growth, photosynthesis, and respiration rates of Gymnodinium breve under varying light levels. In: Smayda T, Shimizu $\mathrm{Y}$ (eds) Toxic phytoplankton blooms in the sea. Proc 5th Int Conf Toxic Marine Phytoplankton. Developments in marine biology, Vol 3. Elsevier, Amsterdam, p 1-2

Shimizu Y, Watanabe N, Wrensford G (1995) Biosynthesis of brevetoxins and heterotrophic metabolism in Gymnodinium breve. In: Lassus P, Arzul G, Erard-Le Denn E, Gentien P, Marcaillou-Le Baut C (eds) Harmful marine algal blooms. Lavoisier, Paris, p 351-357

Sinclair G (2005) Environmental and behavioral influences on Karenia brevis' nitrate uptake. North Carolina State University, Raleigh, NC

Sinclair G, Kamykowski D (2006) The effects of physiology and behaviour on the near-bottom distributions of Karenia brevis on the West Florida shelf: a numerical study. Afr J Mar Sci 28:361-364

Sinclair GA, Kamykowski D (2008) Benthic-pelagic coupling in sediment-associated populations of Karenia brevis. J Plankton Res 30:829-838

Sinclair GA, Kamykowski D, Milligan E, Schaeffer B (2006a)
Nitrate uptake by Karenia brevis. I. Influences of prior environmental exposure and biochemical state on diel uptake of nitrate. Mar Ecol Prog Ser 328:117-124

Sinclair GA, Kamykowski D, Milligan E, Schaeffer B (2006b) Nitrate uptake by Karenia brevis. II. Behavior and uptake physiology in a nitrate-depleted mesocosm with a bottom nutrient source. Mar Ecol Prog Ser 328:125-131

Sinclair G, Kamykowski D, Glibert PM (2009) Growth, uptake, and assimilation of ammonium, nitrate, and urea, by three strains of Karenia brevis grown under low light. Harmful Algae 8:770-780

Steidinger KA (1975) Implications of dinoflagellate life cycles on initiation of Gymnodinium breve red tides. Environ Lett 9:129-139

Steidinger K (1983) A re-evaluation of toxic dinoflagellate biology and ecology. Prog Phycol Res 2:147-188

> Steidinger KA, Ingle R (1972) Observations on the 1971 summer red tide in Tampa Bay, Florida. Environ Lett 3: 271-278

Steidinger K, Vargo G, Tester P, Tomas C (1998) Bloom dynamics and physiology of Gymnodinium breve with emphasis on the Gulf of Mexico. NATO ASI Ser Ser G Ecol Sci 41:133-153

Stoecker DK (1999) Mixotrophy among dinoflagellates. J Eukaryot Microbiol 46:397-401

Stumpf RP, Litaker RW, Lanerolle L, Tester PA (2008) Hydrodynamic accumulation of Karenia off the west coast of Florida. Cont Shelf Res 28:189-213

Tester P, Steidinger K (1997) Gymnodinium breve red tide blooms: initiation, transport, and consequences of surface circulation. Limnol Oceanogr 42:1039-1051

van Dolah F, Leighfield T (1999) Diel phasing of the cell Cycle in the Florida red tide dinoflagellate, Gymnodinium breve. J Phycol 35:1404-1411

- Walsh JJ, Penta B, Dieterle DA, Bissett WP (2001) Predictive ecological modeling of harmful algal blooms. Hum Ecol Risk Assess An Int J 7:1369-1383

- Walsh JJ, Weisberg RH, Dieterle DA, He R and others (2003) Phytoplankton response to intrusions of slope water on the West Florida Shelf: Models and observations. J Geophys Res 108, C6, 3190, doi:10.1029/2002JC001406

> Walsh JJ, Jolliff J, Darrow B, Lenes J and others (2006) Red tides in the Gulf of Mexico: Where, when, and why? J Geophys Res 111, C11003, doi:10.1029/2004JC002813

> Weisberg RH, He R (2003) Local and deep-ocean forcing contributions to anomalous water properties on the West Florida Shelf. J Geophys Res 108, C6, 3184, doi:10.1029/ 2002JC001407

Williams PJleB, Morris PJ, Karl DM (2004) Net community production and metabolic balance at the oligotrophic ocean site, station ALOHA. Deep-Sea Res I 51:1563-1578

Wilson W (1966) The suitability of sea-water for the survival and growth of Gymnodinium breve (Davis); and some effects of phosphorus and nitrogen on its growth. Fla Board Conserv Mar Lab Prof Pap Ser 7:1-42

> Yamazaki AK, Kamykowski D (2000) A dinoflagellate adaptive behavior model: response to internal biochemical cues. Ecol Model 134:59-72 
Appendix. STELLA model formula and parameter definitions

The carbon content of a $K$. brevis cell ranges from 36 to 90 pmol (Heil 1986) and the cellular nutrient concentration from nitrogen compounds, cellular $[\mathrm{N}]$, exclusive of protein ranges from 5 to 20 pmol, derived by subtracting protein from the measured 6.32 to 23.30 pmol [N] cell ${ }^{-1}$ (Kamykowski et al. 1998a as in Liu et al. 2001b), which is within the range of 3.3 to $15.4 \mathrm{pmol}^{\mathrm{N}} \mathrm{cell}^{-1}$ reported by Heil (1986). In our model, a newly divided daughter cell receives half of the maximum carbon pool (45 pmol) and nutrient pool (10 pmol). Because dinoflagellates divide at species-specific times of day (Berdalet et al. 1992), and $K$. brevis has been observed dividing a few hours prior to sunrise, cellular division in our model took place at 03:00 h, as in a previous biophysical model (Liu et al. 2001a).

The depth of the cell at time $(t)$ is:

$\operatorname{Depth}(t)=\operatorname{Depth}(t-\mathrm{d} t)+\left(\operatorname{Cell}_{\mathrm{NU}}-\operatorname{Cell}_{\mathrm{CU}}-z_{\mathrm{Lim}}\right) \cdot \mathrm{d} t \quad(\mathrm{~A} 1)$ where Cell $_{\mathrm{CU}}$ is the ascending swimming speed:

Cell $_{\mathrm{CU}}=$

$1.4-\left(\right.$ Cell $_{\mathrm{C}} /$ Cell $\left.\left._{\mathrm{CMax}}\right) \mathrm{m} \mathrm{h}^{-1}\right\}$ 00:00 h-12:00 h, else 0

Cell $\mathrm{NU}_{\mathrm{NU}}$ is the descending swimming speed:

Cell $_{\mathrm{NU}}=$
$1.4-\left(\right.$ Cell $_{\mathrm{N}} /$ Cell $\left.\left._{\mathrm{NMax}}\right) \mathrm{m} \mathrm{h}^{-1}\right\}$ 12:00 h-00:00 h, else 0

and $z_{\text {Lim }}$ reduces the swimming speed once the sedimentwater interface is reached, to limit the ability of the cells to migrate into the interstitial spaces in the sediment (Sinclair \& Kamykowski 2008) during descent. Cell ${ }_{\mathrm{C}}$ and $\mathrm{Cell}_{\mathrm{N}}$ are the internal concentrations of carbon and $[\mathrm{N}]$ at time $t$. Cell ${ }_{\mathrm{CMax}}$ and Cell $\mathrm{NMax}_{\text {are }}$ the maximum internal concentrations of carbon and [N] needed for cellular division. Swimming speed will decrease as the cellular pool fills, from $0.9 \mathrm{~m} \mathrm{~h}^{-1}$ to $0.5 \mathrm{~m} \mathrm{~h}^{-1}$ as the cellular pool reaches maximum capacity. The cell swims upwards faster than downwards if it requires more carbon from photosynthesis than nutrients. A large nutrient deficit will make downward migration faster than upward migration; therefore, nutrient depleted $K$. brevis will remain low in the water column for longer periods of time than nutrient replete cells (Liu et al. 2001b). In this model, division produces 2 identical daughter cells when both the nutrient and carbon pools become at least $90 \%$ full simultaneously (Kamykowski et al. 1998a).

The internal cellular carbon content, $\mathrm{Cell}_{\mathrm{C}}$, is:

$\operatorname{Cell}_{\mathrm{C}}(t+1)=\left[\operatorname{Cell}_{\mathrm{C}}(t)+\operatorname{Cell}_{\mathrm{C}}(t)_{\mathrm{Uptake}}-\operatorname{Cell}_{\mathrm{C}}(t)_{\text {Resp }}\right] \cdot \mathrm{d} t$

with an uptake rate determined by Michaelis-Menten kinetics:

$$
\text { Cell }_{\mathrm{C}}(t)_{\text {Uptake }}=\left[\left(C_{\mathrm{lm}} \cdot I_{\mathrm{Z}}\right) /\left(\mathrm{K}_{\mathrm{i}}+I_{\mathrm{z}}\right)\right] \cdot \mathrm{d} t
$$

where $C_{\mathrm{Im}}$ is the maximum carbon intake rate of $2 \mathrm{pmol} \mathrm{C}$ $\mathrm{h}^{-1}$ cell $^{-1}$, calculated from the uptake needed to refill the $\mathrm{C}$ pool (halved at division) by fixing 45 pmol carbon using a typical expected light exposure of $8 \mathrm{~h} \mathrm{~d}^{-1}$ over the $3 \mathrm{~d}$ cell cycle typical for the Wilson clone of $K$. brevis in a nutrientreplete environment (Shanley \& Vargo 1993). This is net photosynthetic rate, encompassing dark respiration and carbon loss due to protein synthesis. $\mathrm{K}_{\mathrm{i}}$ is the light half saturation constant of $50 \mu \mathrm{mol}$ quanta $\mathrm{m}^{-2} \mathrm{~s}^{-1}$, indicating a dark adapted $K$. brevis cell and mid-range between 31 and $67 \mu \mathrm{mol} \mathrm{m} \mathrm{m}^{-2} \mathrm{~s}^{-1}$ (Magana \& Villareal 2006), and $I_{z}$ is the vertical light intensity gradient in the water column, determined using Beer's law of light attenuation:

$$
I_{z}=I_{0} \mathrm{e}^{-k z}
$$

where $z$ is the cell depth (m) from the surface, $I_{0}$ is the incident light at the surface, and $k$ is the typical attenuation coefficient for the Gulf of Mexico of $0.1\left(\mathrm{~m}^{-1}\right)$ as in Yamazaki \& Kamykowski (2000). In this model, $I_{\text {o }}$ was a sinusoidal function with all negative values of the sine wave interpreted as 0 . Cellular respiration was calculated assuming a $5 \%$ loss, e.g. (Williams et al. 2004) as:

$$
\operatorname{Cell}_{\mathrm{C}}(t)_{\text {Resp }=}\left(0.05 \cdot \mathrm{C}_{\mathrm{lm}}\right) \cdot \mathrm{d} t \text {, when } I_{\mathrm{o}}=0
$$

The total internal nutrient content of a cell at each time step, Cell ${ }_{N}$, is:

$\operatorname{Cell}_{\mathrm{N}}(t+1)=\left[\mathrm{Cell}_{\mathrm{N}}(t)+\operatorname{Cell}_{\mathrm{N}}(t)_{\text {Uptake }}-\operatorname{Cell}_{\mathrm{N}}(t)_{\text {Leakage }}\right] \cdot \mathrm{d} t$

with uptake governed by the Michaelis-Menten equation:

$\mathrm{Cell}_{\mathrm{N}}(t+1)_{\text {Uptake }}=\left[\left(\mathrm{VM}_{\mathrm{NO} 3} \cdot \mathrm{NO}_{3}\right) /\left(\mathrm{K}_{\mathrm{NO} 3}+[\mathrm{N}]\right)\right] \cdot \mathrm{d} t$

where $\mathrm{K}_{\mathrm{NO}_{3}}$ is the nitrate half saturation constant for nutrients, $\mathrm{VM}_{\mathrm{NO}_{3}}$ is the maximum nutrient uptake, defined below, and $[\mathrm{N}]$ is the external nutrient concentration that we are varying in this experiment. This model uses $\mathrm{K}_{\mathrm{NO}_{3}}$ of $0.4 \mu \mathrm{M}[\mathrm{N}]$, a value between those of 2 clonal isolates, $0.42 \mathrm{\mu M} \mathrm{NO}_{3}{ }^{-}$(Steidinger et al. 1998) and $0.39 \mathrm{\mu M} \mathrm{NO}_{3}{ }^{-}$ (G. Sinclair pers. obs.), both for cell populations grown in low light. Laboratory-determined values for the maximum nutrient uptake were not available at the time of this study, so we modulated the uptake rate as a function of the internal nutrient concentration using a simplified version of the equation developed by Liu et al. (2001a), which generates a linearly decreasing nutrient uptake rate that should fill the cellular pool in $3 \mathrm{~d}$ under nutrient replete conditions for a variety of initial nutrient conditions.

$$
\begin{aligned}
\mathrm{VM}_{\mathrm{NO} 3} & =0.6 \cdot \mathrm{e}^{(-0.01 \cdot \text { CellN })} \text { when } I_{\mathrm{z}}>0[\text { Light uptake] } \\
\mathrm{VM}_{\mathrm{NO} 3} & =0.3 \cdot \mathrm{e}^{(-0.01 \cdot \text { CellN })} \text { when } I_{\mathrm{z}} \leq 0[\text { Dark uptake] }
\end{aligned}
$$

It should be noted that because these cells were encountering nutrients only near the benthos at the lower bound of their downward migration, which occurred at night, the $\mathrm{VM}_{\mathrm{NO}_{3}}$ value was always calculated from the dark uptake equation (Eq. A11), which is expected to be more conservative than the true uptake rate in low-nutrient conditions (Sinclair et al. 2006a). The cellular leakage rate:

$\operatorname{Cell}_{\mathrm{N}}(t)_{\text {Leakage }}=\left\{\left[\left(\mathrm{VM}_{\mathrm{NO}_{3}} \cdot 0.1\right) /\left(\mathrm{K}_{\mathrm{NO}_{3}}+0.1\right)\right] \cdot 0.5\right\} \cdot \mathrm{d} t$

was calculated as $50 \%$ of the uptake rate at a nutrient concentration of $0.1 \mu \mathrm{M} \mathrm{NO} \mathrm{NO}_{3}$ to account for the fact that growth is not known to occur in nutrient concentrations below $0.1 \mu \mathrm{M}$. 